\title{
Distribution, habitat and status of 'Endangered' Sakalava Rail of Madagascar
}

\author{
MARC RABENANDRASANA, SAMA ZEFANIA, PETER LONG, \\ SAM THE SEING, MARIE CLÉMENTINE VIRGINIE, \\ MIHAJA RANDRIANARISOA, ROGER SAFFORD and TAMÁS SZÉKELY
}

\section{Summary}

The 'Endangered' Sakalava Rail Amaurornis olivieri is endemic to wetlands in western Madagascar, where it has been recorded between the Betsiboka river in the north and the Mangoky river in the south. Between August 2003 and November 2006, including dry and wet seasons, we surveyed 36 potentially suitable wetlands throughout its known range. We found Sakalava Rails at five sites: Lacs Kinkony, Ampandra, Amparihy, Sahapy and Mandrozo. At each site the population was small (12-39 individuals) and the highest density was 20 individuals $\mathrm{km}^{-2}$. We found up to 67 birds in each field visit and the total number of birds (sum of maxima at each site) seen was 10o. We estimate the total population at the five sites to be 215 rails. We cannot confirm that the population lies within the range estimated in the current Red List (250-999 individuals), although this may yet be proven correct. The typical breeding habitat of Sakalava Rail is lotic marshes with a mixture of large areas of open water, reed Phragmites mauritianus and floating Salvinia hastata. The major threats to Sakalava Rail appear to be habitat loss caused by wetland conversion to rice fields and by fires, disturbance by fishermen and people from local villages, and hunting. Other processes that may alter the ecological character of wetlands and so affect their suitability for Sakalava Rails, such as hydrological change or the effects of exotic fish or vegetation, remain to be investigated.

\section{Introduction}

The Sakalava Rail Amaurornis oliveri is a wetland bird endemic to western Madagascar, currently classified globally as 'Endangered', based on its small and severely fragmented population, and threats from the widespread and rapid degradation and destruction of wetlands in Madagascar (BirdLife International 2004). Its description was based on a specimen collected at an unspecified location between Maintirano and Antsalova (Grandidier and Berlioz 1929). It was recorded only twice before 1985 (Collar and Stuart 1985): seven specimens were collected by the Franco-Anglo-American Expedition at Ambararatabe on the Tsiribehino or Tsiribahina (two alternative spellings used) river, between Lake Kinkony and the Mahavavy River, in March 1931 (Rand 1936), and a female was taken from a nest at Nosy-Ambositra on the Mangoky River, a short distance upstream of the delta, in March 1962 (Benson and Wagstaffe 1972). Between 1995 and mid-2003, Sakalava Rails were found at four localities: (1) a single individual in 1995 at Lac Bemamba, west of Antsalova (Ramanampamonjy 1995), with another sighting there, mentioned without details, in 1999 (Harebottle 1999); (2) two in 2001 at Amboropotsy marsh, $30 \mathrm{~km}$ south of Bekopaka (Willard and Goodman 2002); (3) four adults with two chicks at Lac Ampandra near Besalampy in November 2002 (Robertson 2004); and (4) at least one pair at a marsh in Lac Kinkony, near Makary village, in April and May 2003 (Anon. 2003, Rabenandrasana 
et al. 2004, Rabenandrasana et al. 2007). The latter record is within a few kilometres of where Rand (1936) had found rails 72 years earlier; the river is called the Tsiribihy by Foiben Taosarintanin'i Madagasikara (1956).

These few observations and the suggestion of a declining population estimated at 250-999 individuals (BirdLife International 2004) prompted us to initiate an extensive survey from 2003 to 2006 over the whole historic geographic range of this species. The objective of our study was to collect new information on distribution, ecology and population of this species. We surveyed potentially suitable Sakalava Rail habitats to assess its conservation status, and made notes about threats to the populations.

\section{Methods}

Fieldwork was carried out from 5 August to 31 October 2003 (dry season), 6 March to 21 April 2004 (wet season), 6 to 13 September and 26 October to 11 November 2004 (dry season), March and April 2005 (wet season), October 2005 (dry season), 14 July to 5 August 2007 and 11 October to 22 November 2006 (dry season) by Marc Rabenandrasana, Sama Zefania, Sam The Seing, Marie Clémentine Virginie and M. Randrianarisoa, with supplementary observations added by the other authors. We used 1:50,000-1:500,000 maps (from the National Cartography Centre Foiben Taosarintanin'i Madagasikara) to identify freshwater marshes between the Betsiboka and Mangoky Rivers in the western lowlands of Madagascar. We visited 36 potentially suitable wetlands (Figure 1). We attempted to survey each site both in the wet and dry seasons, but road conditions restricted our access to some sites in the wet season.

Before beginning the surveys, we met local people including the village leader, fishermen and older people, and asked them whether they had seen Sakalava Rails. We also probed into the knowledge of villagers about their wetland birds to assess the reliability of their statements about Sakalava Rail. Finally, we showed them a colour plate of the Sakalava Rail, and other rails that occur in western Madagascar.

Our early results, like previous observations, suggested that the Sakalava Rail's preferred habitat is stands of reed Phragmites mauritianus, known locally as bararata (and often incorrectly referred to as $P$. communis). Therefore, at each village, we also asked local people about Phragmites marshes around their village, and with a guide and a small pirogue we entered the clearings of the Phragmites marshes. These wetlands are inhabited by Nile Crocodiles Crocodylus niloticus, thus fieldwork required care. We divided each site into sections, and established an observation point in each section. Censuses were carried out using binoculars between 06 hoo and 10hoo, and between 16 hoo and 18hoo, local time. At each observation point we stayed for a period of time (from few minutes to hours), and listened carefully for Sakalava Rail calls. We then played back Sakalava Rail calls using a SONY TCM 50oDV tape recorder. At each site we counted the number of rails (including downy young, which were, however, not included in population estimates), took coordinates to allow demarcation of the area of suitable Sakalava Rail habitat using a hand-held GPS device, took the coordinates of each rail observation, recorded the locality name or the nearest village, and noted the date and time of survey. We also collected data on habitat, threats and behaviour of rails, and information on other threatened birds. The area of surveyed habitat was later estimated by creating shape files from coordinates, then joining them to create polygons, which were projected into a Universal Transverse Mercator coordinate system. Sakalava Rail density was estimated from the number of birds recorded during a survey divided by the area covered by the survey, and population size in a given area was estimated by multiplying this density by the total area of suitable habitat including unsurveyed areas. The total population at a given site was then estimated as the total of all areas. A rigorous estimate of global population will require further analysis using remote sensing and GIS techniques, as has recently been achieved for the Madagascar Plover Charadrius thoracicus (Long et al. 2008). 


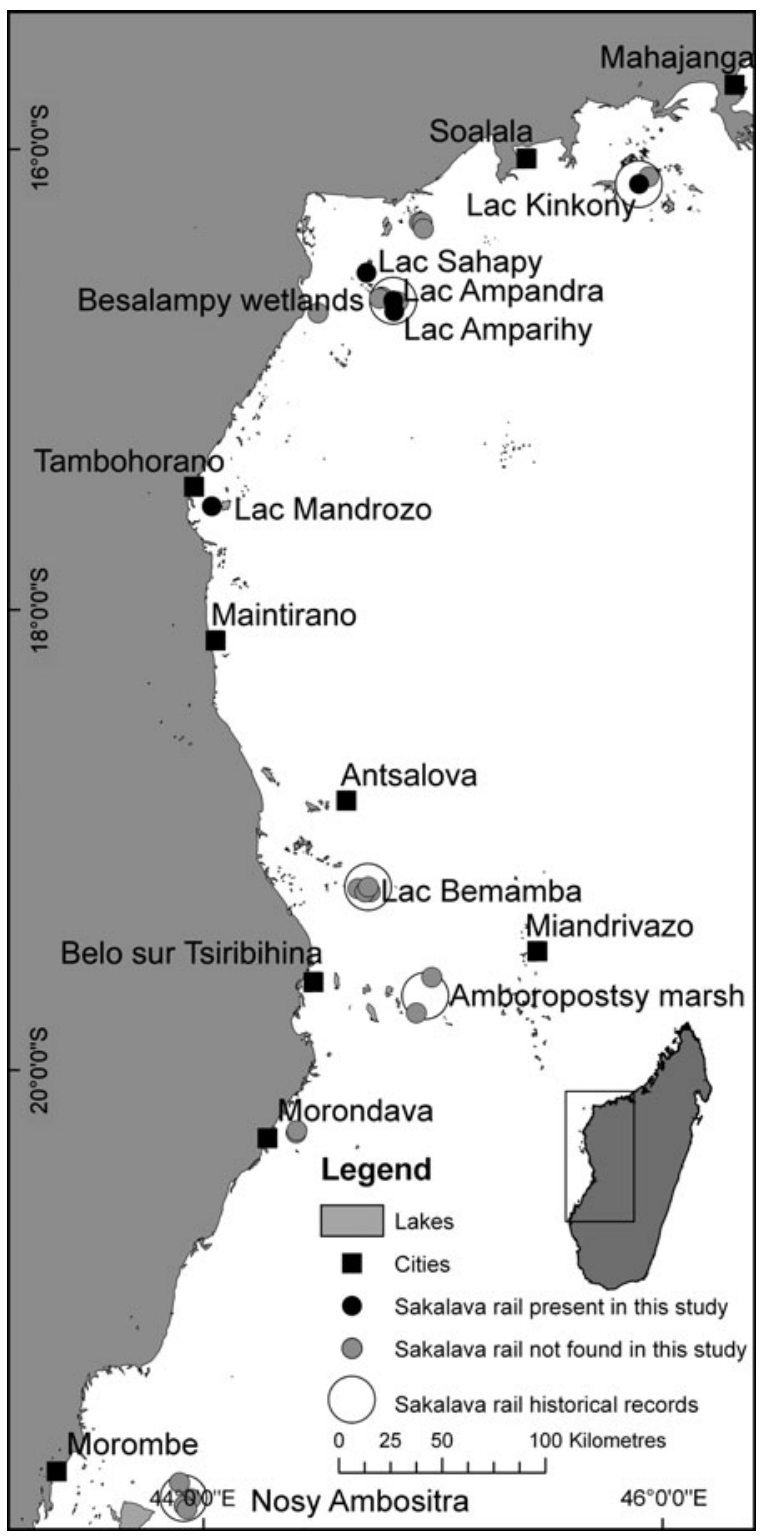

Figure 1. Distribution of Sakalava Rail showing historic sites, and sites surveyed in 2003-2006.

\section{Results}

\section{Distribution and population size}

We found Sakalava Rails at five sites. Birds were present at Lacs Ampandra and Kinkony, where they had been found in 2002 and 2003. At Kinkony, Sakalava Rails were found in two marshes close to Makary village, referred to as Anjanaboro and Makary marshes. The other three occupied sites were new discoveries: Lac Amparihy and Lac Sahapy, in the Besalampy area wetland complex, and Lac Mandrozo, $100 \mathrm{~km}$ to the south near Tambohorano (Figure 1). We did not 
record Sakalava Rail at three sites where they had been recorded before 2002: Lac Bemamba, Amboropotsy marsh and Nosy Ambositra marsh (Table 3).

Between August and October 2003 we observed a total of 67 birds at four sites, three of which are in the Besalampy region. Population density was estimated only at Lac Kinkony, at 6.I individuals $\mathrm{km}^{-1}$ (Table 1 ). The latter estimate included two pairs that built their nests in October 2003 .

In 2004 we visited Lac Kinkony during the wet season (January to March) and dry season (September to October). The survey in wet season was interrupted by two cyclones, which made most sites inaccessible; floating Salvinia hastata had been blown to the edge of the lake, and Phragmites beds severely damaged, but we found 1o Sakalava Rails in the accessible part of the lake $\left(5.1 \mathrm{~km}^{-2}\right)$, which is only slightly less than in the dry season when 12 individuals were recorded, as in 2003.

In 2005 we visited two lakes: Lac Kinkony (March and April) and Lac Mandrozo (October). We confirmed the presence of 15 individuals at Lac Kinkony $\left(7.8 \mathrm{~km}^{-2}\right)$ and 12 at Lac Mandrozo $\left(17.3 \mathrm{~km}^{-2}\right)$.

Table 1. Population size and density of Sakalava Rails in western Malagasy wetlands between 2003 and 2006. Missing data are indicated by -

\begin{tabular}{|c|c|c|c|c|c|}
\hline Site & Survey date & $\begin{array}{l}\text { No. of rails } \\
\text { observed }\end{array}$ & $\begin{array}{l}\text { Lake } \\
\text { surface } \\
\mathrm{km}^{2}\end{array}$ & $\begin{array}{l}\text { Phragmites } \\
\text { surface } \\
\mathrm{km}^{2}\end{array}$ & $\begin{array}{l}\text { Rail } \\
\text { density } \\
\mathrm{km}^{-2}\end{array}$ \\
\hline \multicolumn{6}{|l|}{2003} \\
\hline 1. Lac Kinkony & $\begin{array}{l}23 \text { September } \\
\text { to } 11 \text { October }\end{array}$ & 12 & 124.4 & 2.0 & 6.1 \\
\hline 2. Lac Ampandra & 15 September & 12 & 0.7 & - & - \\
\hline 3. Lac Amparihy & $\begin{array}{l}18 \text { to } 22 \\
\text { September }\end{array}$ & 21 & 8.4 & - & - \\
\hline 4. Lac Sahapy & $\begin{array}{l}22 \text { to } 23 \\
\text { September }\end{array}$ & 22 & 17.2 & - & - \\
\hline $\begin{array}{l}\text { 5. Lac Mandrozo } \\
\text { Total }\end{array}$ & & $\begin{array}{l}- \\
67\end{array}$ & $17 \cdot 3$ & - & - \\
\hline \multicolumn{6}{|l|}{2004} \\
\hline 1. Lac Kinkony & $\begin{array}{l}6 \text { to } 15 \\
\text { April }\end{array}$ & 10 & 139.0 & 2.0 & 5.1 \\
\hline 1. Lac Kinkony & $\begin{array}{l}6 \text { to } 13 \\
\text { September } \\
\text { and } 26 \text { October } \\
\text { to } 11 \text { November }\end{array}$ & 12 & 124.4 & 2.0 & 6.1 \\
\hline $\begin{array}{l}\text { Total } \\
2005\end{array}$ & & 12 & & & \\
\hline 1. Lac Kinkony & $\begin{array}{l}29 \text { March } \\
\text { to II April }\end{array}$ & 15 & 139.0 & 2.0 & 7.6 \\
\hline $\begin{array}{l}\text { 5. Lac Mandrozo } \\
\text { Total (maximum) } \\
2006\end{array}$ & 13 October & $\begin{array}{l}12 \\
27\end{array}$ & $17 \cdot 3$ & - & - \\
\hline 1. Lac Kinkony & - & - & 124.4 & - & - \\
\hline 2. Lac Ampandra & $\begin{array}{l}23 \text { to } 27 \\
\text { October }\end{array}$ & 9 & 0.7 & 0.5 & 19.7 \\
\hline 3. Lac Amparihy & $\begin{array}{l}29 \text { October } \\
\text { to } 05 \text { November }\end{array}$ & 39 & 8.4 & 2.2 & $17 \cdot 7$ \\
\hline 4. Lac Sahapy & $\begin{array}{l}7 \text { to } 11 \\
\text { November }\end{array}$ & 3 & 17.2 & 0.6 & 5.0 \\
\hline $\begin{array}{l}\text { 5. Lac Mandrozo } \\
\text { Total (maximum) }\end{array}$ & - & $\begin{array}{l}- \\
51\end{array}$ & $17 \cdot 3$ & - & - \\
\hline
\end{tabular}


Our fourth survey in 2006 (July to November) was conducted only during the dry season around the Besalampy wetland complex. We found 51 rails (Table I) at Lac Amparihy (39 individuals), Lac Ampandra (9 individuals) and Lac Sahapy (3 individuals). Lac Amparihy held the largest population of Sakalava Rail, and Lac Ampandra the highest density $\left(19.7 \mathrm{~km}^{-2}\right)$ yet found.

The sum of the maximum counts at the five sites inhabited by Sakalava Rails gives a total of 100 birds at these sites; the maximum observation within one year was 67 individuals. Extrapolating from these surveys to a global population estimate has several problems, such as assessing the area of habitat (Phragmites beds have never been mapped separately, and the possibility of occupancy of other habitats needs to be considered), appropriate densities to apply, and what occupancy of availably habitat is assumed. A global total in the two hundreds seems most likely (Table 2).

\section{Habitats}

All observations of Sakalava Rail were in marshes with dense beds of Phragmites, 2-3 m tall, with typical associated plant species of Polygonum sp. and Echinochloa pyramidalis. The floating vegetation among the Phragmites was mostly composed of native Salvinia hastata, known locally as ramilamina, water lilies Nymphaea lotus, $N$ stellata and in some areas exotic water hyacinth Eichhornia crassipes. Sakalava Rails occurred only in Phragmites marshes even though there were other habitats devoid of rails: for example at Lac Kinkony in 2003-6, Phragmites habitat represented only $3.8 \%$ of the total lake surface, whereas Lac Ampandra the Phragmites covered $85 \%$ of the total lake surface, so that the much smaller site had the highest Sakalava Rail density (Table 2).

\section{Behaviour and calls}

Sakalava Rails are tame, and when we saw them they were either alone or in pairs. When feeding, they usually walk slowly over floating Salvinia hastata, keeping among the Phragmites stems and avoiding exposed habitats used by other rails such as the Purple Swamphen Porphyrio porphyrio and Allen's Gallinule Porhyrula alleni. When disturbed by human observers or other animals, they run, with brief flights, into dense Phragmites.

We saw rails turning Salvinia hastata with their bills presumably to catch aquatic invertebrates among the roots. Sakalava Rails' tic-tic or tic-tic-tic huaww vocalisations were accompanied with upward flicking movements of the tail. Another vocalisation was made by a Sakalava Rail pair simultaneously as contact call, presumably to recognize each partner: truwrurururururururururu, every 4-6 seconds. During contact calls they are motionless. Sakalava Rail chicks often made very loud calls: kiouw, repeated every 3 to 5 seconds, which might attract predators to the brood especially when adults busy feeding, although we did not observe any predation.

\section{Reproduction and breeding period}

Three active nests were found at Lac Kinkony in 2003: single nests under construction on 30 September and 11 October, and one nest with an adult incubating on 20 November; the third nest was within a few mtres of the first, and so may have involved the same pair which had not been monitored in between. One nest at Lac Mandrozo on 13 October 2005 contained two eggs, and one nest with three fresh eggs was at Lac Amparihy in 6 November 2006. At Lac Amparihy a pair was brooding two downy chicks approximately one week old on 30 July 2006; assuming an incubating period lasting 13-19 days as for the similar Black Crake Amaurornis flavirostra of Africa (Taylor and van Perlo 1999), this suggests egg-laying in early July. Therefore, observations of active nests and downy young indicated laying dates between July and November; however, previous observations show that egg-laying extends into the wet season, based on well-grown 
young seen with adults on 26 March (Rand 1936) and a nest, also with two eggs, in March (Benson and Wagstaffe 1972). Sakalava Rails may nest year round, as does the Black Crake (Taylor and van Perlo 1999), but seasonal peaks remain possible, and perhaps likely in view of our observations in September to November.

The two pairs recorded at Lac Kinkony were observed nest-building in 2003. One nest was built on a floating island made from dead Phragmites leaves and dry Salvinia hastata leaves. The second nest was $0.5 \mathrm{~m}$ above the water level inside a deep tunnel through Phragmites, accessible from only one side. At both nests we observed two individuals, presumably the adult male and female, bringing materials and constructing the nest between o6h3o and oghoo. While they were constructing the nest, the rails only used the immediate surrounding of their nest site within 30-40 m of their nest. Visits to nest sites used in previous years suggested that sites were not re-used.

One nest was observed from 3 to 6 November 2006 at Lac Amparihy before the rail pair started to lay. The nest was constructed in a deep tunnel of Phragmites $0.7 \mathrm{~m}$ above water level, like the second Lac Kinkony nest, described above. External measurements were $136 \mathrm{~mm}$ long, $133 \mathrm{~mm}$ wide and $67 \mathrm{~mm}$ internal deep. It contained three pale creamy eggs with brown markings $(33.3 \mathrm{x}$ $26.5 \mathrm{~mm}, 34.3 \times 27.3 \mathrm{~mm}, 35.2 \times 29.9 \mathrm{~mm}$ ) with weights of $14.5 \mathrm{~g}$, $14 \mathrm{~g}$ and $14.4 \mathrm{~g}$, respectively.

Males and females appear to be distinguished by body size, shape and the colour of the upperparts and legs, and also adults from the immature; these observations will be published elsewhere.

\section{Threats}

The major threats to this species appear to be habitat loss and human disturbance. In all five sites where we found Sakalava Rails, the shallow edges of the marshes had been converted into rice fields. If habitat conversion continues, this would be a final blow to the remaining populations. We also noted that locals burn Phragmites prior to rice cultivation, and collect Phragmites for traditional house construction. Fishermen disturb the habitat, and we also encountered hunters from local villages who hunt waterbirds including Sakalava Rails. Consumption of Sakalava Rails appears to be common practice among villagers around the remaining Sakalava Rail area. A natural threat may come from cyclones, which cause severe short-term disruption to wetland habitat, as was noted at Lake Kinkony in 2004; even if direct mortality is avoided, rails may be forced to more open areas such as lake edges, where they are vulnerable to human disturbance and predation by stray dogs and cats.

The Sakalava Rail runs to deep Phragmites if predators, such as Yellow-billed Kite Milvus aegyptius or Madagascar Coucal Centropus toulou, appear. Adults may be taken by raptors or mammals such as Black Rat Rattus rattus, although we have no direct observations. Predation may also affect nests and fledglings: at Lac Kinkony November 2004 three or four chicks disappeared from one brood during a two-week period, probably due to predation.

\section{Discussion}

Our study found that the Sakalava Rail populations are small: the most birds recorded and estimated at any one site were 39 and 62 birds respectively (Table 2). Lac Kinkony and Lac Mandrozo are separated from the other three sites by over $100 \mathrm{~km}$ (Figure 1 ); even allowing that populations might exist between these sites, the Sakalava Rail appears to have a severely fragmented population. The reasons why we did not find Sakalava Rails in two wetlands (Lac Bemamba and Nosy Ambositra marsh) where the species had previously been recorded might be local extinction, seasonal or year-to-year movement, or that the populations do persist but are small and consequently overlooked. We found that Sakalava Rails do not nest in the same places year after year, and Rand's 1931 site near Lac Kinkony (the Tsiribihy River) has been searched repeatedly but no Sakalava Rails found, although they are nearby at Makary marsh in Lac Kinkony. 
Table 2. Population size estimates of Sakalava Rails in Western Malagasy wetlands 2003 to 2006.

\begin{tabular}{lllllll}
\hline Site & $\begin{array}{l}\text { Maximum } \\
\text { number of } \\
\text { rails } \\
\text { recorded }\end{array}$ & $\begin{array}{l}\text { Lake } \\
\text { surface } \\
\text { (dry season) } \\
\mathrm{km}^{2}\end{array}$ & $\begin{array}{l}\text { Phragmites } \\
\text { surface } \mathrm{km}^{2}\end{array}$ & $\begin{array}{l}\text { Rail } \\
\text { density } \\
\mathrm{km}^{-2}\end{array}$ & $\begin{array}{l}\text { Estimated } \\
\text { maximum } \\
\text { population } \\
\text { size }\end{array}$ & $\begin{array}{l}\text { \% lake } \\
\text { surface } \\
\text { covered by } \\
\text { Phragmites }\end{array}$ \\
\hline 1. Lac Kinkony** & 15 & 124.43 & 5.7 & 7.6 & 43 & 4.5 \\
2. Lac Ampandra* & 12 & 0.74 & 0.6 & 19.7 & 12 & 84.5 \\
3. Lac Amparihy*** & 39 & 8.37 & 3.2 & 17.7 & 57 & 38.3 \\
4. Lac Sahapy* & 22 & 17.19 & 2.5 & 16.55 & 42 & 14.8 \\
5. Lac Mandrozo** & 12 & 17.29 & 3.5 & 17.4 & 62 & 20.5 \\
Total & 100 & & & & 215 & \\
\hline
\end{tabular}

${ }^{*}$ Visual observation in 2003

$* *$ Visual observation in 2005

$* *$ Visual observation in 2006

Our surveys had two potential limitations. Firstly, we focused on Phragmites and could consequently have overlooked other breeding habitats. However, the association with Phragmites is considered to be genuine, because we searched in all types of freshwater wetland, including Typha swamp and sedge (Cyperaceae), which are the other major rail habitats in the region. In addition, information from locals would have revealed other breeding habitats, if any existed. Secondly, we confined our searches to the area between the Betsiboka and Mangoky Rivers and the true distribution may prove to be wider, as for other species of western Malagasy wetlands. However, by far the largest freshwater wetlands are found in this region; it would be preferable to search more widely but it would be very surprising if large numbers of Sakalava Rails were found.

Further fieldwork is necessary, preferably combined with GIS-based population modelling, to estimate the population size of Sakalava Rail. Having recorded only 1oo birds, we cannot confirm that the current population lies within the range estimated in the current Red List (250-999 individuals: Birdlife International 2004), although this may yet be proven correct.

Habitat conversion appears to be the major threat to wetland birds in Madagascar, including the Sakalava Rail. None of the five sites is fully protected, although Lake Kinkony received temporary protection in 2007, and it is to be hoped this will be made permanent by 2009. It is imperative to seek full protection of all these sites as soon as possible, by including our newly identified sites in priority-setting for short- and medium-term conservation action under the Malagasy Government's new Protected Area System expansion policy. Lac Mandrozo and the Besalampy wetland complex are, like Lac Kinkony, high conservation priorities that are suitable for a conservation programme involving local communities. Public awareness-raising programmes at sites where Sakalava Rails are found should aim to reduce persecution to which the birds are particularly vulnerable while breeding. However, other processes that may alter the ecological character of wetlands and so affect their suitability for Sakalava Rails, such as hydrological change or the effects of exotic fish or vegetation, remain to be investigated; to tackle any such problems, site protection would probably not be sufficient.

Madagascar has II rail species of which the Kioloides Rail or Madagascar Wood Rail Canirallus kioloides and the Madagascar Flufftail Sarothrura insularis occur in both dry and wet habitats (Langrand 1990); the remaining nine species inhabit wetlands. Six of these nine are endemic to Madagascar, three of them considered threatened with global extinction (BirdLife International 2004; the others are Slender-billed Flufftail Sarothrura watersi and Madagascar Rail Rallus madagascariensis of the eastern wetlands). Thus initiating detailed conservation research on endemic rails is urgently required, because wetland habitats are rapidly disappearing in Madagascar. 
Table 3. Survey sites where Sakalava Rails were not recorded.

\begin{tabular}{|c|c|c|}
\hline Locality & Coordinates and notes & Dates of survey \\
\hline O1. Antongomena, south east of Lac & $\mathrm{S}_{1} 6^{\circ} 10.291^{\prime} \mathrm{E}_{45^{\circ}} 55^{\prime} .087^{\prime}$ & 23 September to \\
\hline Kinkony (Mitsinjo Sous prefecture) & $\begin{array}{l}\text { Similar habitat structure } \\
\text { to Lac Kinkony }\end{array}$ & $\begin{array}{l}\text { I1 October } 2003 \\
\text { and 06-15 April } 2004\end{array}$ \\
\hline o6. Lac Ladika & $\mathrm{S}_{15}{ }^{\circ} 56.661^{\prime} \mathrm{E}_{45^{\circ}} 57 \cdot 308^{\prime}$ & 11-17 September 2003 \\
\hline (Mitsinjo Sous prefecture) & $\begin{array}{l}\text { Similar habitat structure } \\
\text { to Lac Kinkony }\end{array}$ & and 18-19 April 2004 \\
\hline 07. Lac Katondra & $\mathrm{S}_{1} 6^{\circ} 09.068^{\prime} \mathrm{E}_{4} 6^{\circ} 00.700^{\prime}$ & 18-22 September 2003 \\
\hline (Mitsinjo Sous prefecture) & $\begin{array}{l}\text { Similar habitat structure } \\
\text { to Lac Kinkony }\end{array}$ & and $02-04$ April 2004 \\
\hline o8. Tsiribihy river & $\mathrm{S}_{1} 6^{\circ} 09.724^{\prime} \mathrm{E}_{45^{\circ}} 56.090^{\prime}$ & 18-22 September 2003 \\
\hline (Mitsinjo Sous prefecture) & $\begin{array}{l}\text { Near to site where } \\
\text { specimen was collected } \\
\text { by Rand (1936) }\end{array}$ & and $02-04$ April 2004 \\
\hline $\begin{array}{l}\text { o9. Betsivaky marsh or Masama marsh } \\
\text { (Soalala Sous prefecture) }\end{array}$ & $\mathrm{S}_{16} 6^{\circ} 07.106^{\prime} \mathrm{E}_{45^{\circ} 10.847^{\prime}}$ & 29-31 August 2003 \\
\hline $\begin{array}{l}\text { 10. Lac Ambararatabe } \\
\text { (Soalala Sous prefecture) }\end{array}$ & $\mathrm{S}_{1} 6^{\circ} 18.909^{\prime} \mathrm{E}_{44^{\circ}}{ }^{\circ} 6.314^{\prime}$ & 10 September 2003 \\
\hline $\begin{array}{l}\text { 11. Bekadradraky Marsh } \\
\text { (Besalampy Sous prefecture) }\end{array}$ & $\mathrm{S}_{1} 6^{\circ} 19.023^{\prime} \mathrm{E}_{44^{\circ}} 57.139^{\prime}$ & 10-11 September 2003 \\
\hline $\begin{array}{l}\text { 12. Lac Betakilotsy } \\
\text { (Besalampy Sous prefecture) }\end{array}$ & $\mathrm{S}_{1} 6^{\circ} 20.666^{\prime} \mathrm{E}_{44^{\circ}} 57.45^{\prime}$ & 10-11 September 2003 \\
\hline $\begin{array}{l}\text { 13. Mangatsiaka marsh } \\
\text { (Besalampy Sous prefecture) }\end{array}$ & $\mathrm{S}_{1} 6^{\circ} 39.703^{\prime} \mathrm{E}_{44^{\circ}} 50.835^{\prime}$ & 17-18 September 2003 \\
\hline $\begin{array}{l}\text { 14. Lac Ambararata } \\
\text { (Besalampy Sous prefecture) }\end{array}$ & $\mathrm{S}_{1} 6^{\circ} 38.446^{\prime} \mathrm{E}_{44^{\circ}}{ }^{\circ} 6.586^{\prime}$ & 19 September 2003 \\
\hline $\begin{array}{l}\text { 15. Lac Maintimaso } \\
\text { (Besalampy Sous prefecture) }\end{array}$ & $\mathrm{S}_{1} 6^{\circ} 38.564^{\prime} \mathrm{E}_{44^{\circ}}{ }^{\circ} 6.814^{\prime}$ & 20 September 2003 \\
\hline $\begin{array}{l}\text { 16. Ambaloandro marsh } \\
\text { (Besalampy Sous prefecture) }\end{array}$ & $\mathrm{S}_{16} 6^{\circ} 38.775^{\prime} \mathrm{E}_{44^{\circ}} 45.974^{\prime}$ & 20 September 2003 \\
\hline $\begin{array}{l}\text { 17. Andranolava marsh } \\
\text { (Besalampy Sous prefecture) }\end{array}$ & 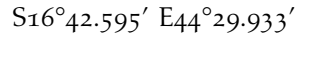 & 25-27 September 2003 \\
\hline $\begin{array}{l}\text { 18. Lac Andranomena } \\
\text { (Belo sur Tsiribihina Sous Prefecture) }\end{array}$ & $\mathrm{S}_{19}{ }^{\circ} 35.822^{\prime} \mathrm{E}_{44^{\circ}} 59.629^{\prime}$ & 04-06 October 2003 \\
\hline $\begin{array}{l}\text { 19. Lac Korombo } \\
\text { (Belo sur Tsiribihina Sous Prefecture) }\end{array}$ & $\mathrm{S}_{19}{ }^{\circ} 45.134^{\prime} \mathrm{E}_{44^{\circ}} 55.582^{\prime}$ & 07-08 October 2003 \\
\hline $\begin{array}{l}\text { 20. Lac Anatsena } \\
\text { (Antsalova Sous Prefecture) }\end{array}$ & $\mathrm{S}_{19}{ }^{\circ} 12.753^{\prime} \mathrm{E}_{44^{\circ}}{ }^{41.058^{\prime}}$ & o9 October 2003 \\
\hline $\begin{array}{l}\text { 21. Amborompotsy marsh } \\
\text { (Antsalova Sous prefecture) }\end{array}$ & 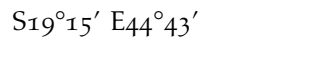 & o9 October 2003 \\
\hline $\begin{array}{l}\text { 22. Tsitabato Lac } \\
\text { (Antsalova Sous Prefecture) }\end{array}$ & $\mathrm{S}_{19}{ }^{\circ} 12.700^{\prime} \mathrm{E}_{44^{\circ}}{ }^{\circ} \mathrm{O} .350^{\prime}$ & o9 October 2003 \\
\hline $\begin{array}{l}\text { 23. Masiaboay marsh } \\
\text { (Antsalova Sous Prefecture) }\end{array}$ & $\mathrm{S}_{19}{ }^{\circ} 13.510^{\prime} \mathrm{E}_{44^{\circ}} 43.596^{\prime}$ & 10 October 2003 \\
\hline $\begin{array}{l}\text { 24. Tsiazohena Lac } \\
\text { (Antsalova Sous Prefecture) }\end{array}$ & $\mathrm{S}_{1} 9^{\circ} 13.572^{\prime} \mathrm{E}_{44^{\circ}}{ }^{\circ} 2.158^{\prime}$ & 10 October 2003 \\
\hline 25. Lac Bemamba & $\mathrm{S}_{19}{ }^{\circ} 12.75^{\prime} \mathrm{E}_{44^{\circ}} 43.055^{\prime}$ & II October 2003 \\
\hline (Antsalova Sous Prefecture) & $\mathrm{S}_{1} 8^{\circ} 49.967^{\prime} \mathrm{E}_{44^{\circ}}{ }^{\circ} 21.465^{\prime}$ & and 04 March 2004 \\
\hline $\begin{array}{l}\text { 26. Lac Kinara } \\
\text { (Morondava Sous Prefecture) }\end{array}$ & $\mathrm{S}_{20}{ }^{\circ} 16.381^{\prime} \mathrm{E}_{44^{\circ}} 24.187^{\prime}$ & 13 October 2003 \\
\hline $\begin{array}{l}\text { 27. Lac Remalaza } \\
\text { (Morondava Sous Prefecture) }\end{array}$ & $\mathrm{S}_{20}{ }^{\circ} 15 \cdot 790^{\prime} \mathrm{E}_{44^{\circ}} 24.4 \mathrm{O}^{\prime}$ & 13 October 2003 \\
\hline
\end{tabular}


Table 3. Continued.

\begin{tabular}{|c|c|c|}
\hline Locality & Coordinates and notes & Dates of survey \\
\hline $\begin{array}{l}\text { 28. Lac Betsioky } \\
\text { (Miandrivazo Sous Prefecture) }\end{array}$ & $\mathrm{S}_{19}{ }^{\circ} 39.852^{\prime} \mathrm{E}_{45^{\circ}} 26.637$ & 20 February 2004 \\
\hline $\begin{array}{l}\text { 29. Lac Isalo } \\
\text { (Miandrivazo Sous Prefecture) }\end{array}$ & No GPS co-ordinates & 21 February 2004 \\
\hline $\begin{array}{l}\text { 3o. Lac Ebofo } \\
\text { (Miandrivazo Sous Prefecture) }\end{array}$ & $\mathrm{S}_{19}{ }^{\circ} 49.966^{\prime} \mathrm{E}_{45^{\circ}} 31.887^{\prime}$ & 22 February 2004 \\
\hline $\begin{array}{l}\text { 31. Lac Antsoha } \\
\text { (Miandrivazo Sous Prefecture) }\end{array}$ & No GPS co-ordinates & 23 February 2004 \\
\hline $\begin{array}{l}\text { 32. Besaka marsh } \\
\text { (Befandrina Sud prefecture) }\end{array}$ & $\mathrm{S}_{21}{ }^{\circ} 51.856^{\prime} \mathrm{E}_{43^{\circ}} 56.767^{\prime}$ & 15 October 2003 \\
\hline $\begin{array}{l}\text { 33. Lac Andremotry } \\
\text { (Befandrina Sud prefecture) }\end{array}$ & $\mathrm{S}_{21^{\circ}}{ }^{4} 7.621^{\prime} \mathrm{E}_{43^{\circ}}{ }^{5} 33.774^{\prime}$ & 17 October 2003 \\
\hline $\begin{array}{l}\text { 34. Lac Ambohidiabe } \\
\text { (Befandrina Sud prefecture) }\end{array}$ & $\mathrm{S}_{21}{ }^{\circ} 54.003^{\prime} \mathrm{E}_{43^{\circ}} 55.306^{\prime}$ & 17 October 2003 \\
\hline $\begin{array}{l}\text { 35. Lac Ambohidiakely } \\
\text { (Befandrina Sud prefecture) }\end{array}$ & $\mathrm{S}_{21}{ }^{\circ} 53.671^{\prime} \mathrm{E}_{43^{\circ}}{ }^{\circ} 54.920^{\prime}$ & 18 October 2003 \\
\hline $\begin{array}{l}\text { 36. Bevatry marsh } \\
\text { (Befandrina Sud prefecture) }\end{array}$ & $\mathrm{S}_{21}{ }^{\circ} 54.594^{\prime} \mathrm{E}_{43^{\circ}} 55.646^{\prime}$ & 18 August 2003 \\
\hline
\end{tabular}

\section{Acknowledgements}

This project was funded by grants to MR and ZS by Conservation International Madagascar (Threatened Species Small Grant), British Ecological Society (Overseas Bursary 2006-2007) and African Bird Club Conservation Award. We thank all administrative and technical staff at Conservation International Centre for Biodiversity Conservation (CBC) Madagascar. Part of the work described here at Lake Kinkony was carried out by BirdLife International Madagascar Programme which also provided technical support and materials for subsequent work in this area. We thank Julien Ramanampamonjy and Dr Ramanitra Narisoa, successive Presidents of Asity Madagascar (Malagasy League for Bird Conservation) and Vony Raminoarisoa, Director of the BirdLife International Madagascar Programme, for advice and permissions. The Department of Animal Biology at the University of Antananarivo, Dr Lily Arison René de Rolland and Mme Rajesy Jeannette at The Peregrine Fund Madagascar programme, the Association Nationale pour la Gestion des Aires Protégées (ANGAP) and the Ministère de l'Environnement, des Eaux et Forêts supported us by providing research permits. PL was supported by a NERC studentship, and TS was funded by a Leverhulme Trust Fellowship (RF/2/RFG/2005/0279) and a Hardy Conservation Fellowship at Harvard University. Finally, we acknowledge the assistance of Richard Thaxton (Royal Society for the Protection of Birds, UK), Jenia Razafinjato (Asity), Claudine Razanajafy, Mr Rasolonandrasana and Mr Randrianantenaina A from the meteorological field station at Besalampy for fieldwork. The manuscript benefited from the comments of Dr Frank Hawkins and an anonymous referee.

\section{References}

Anon. (2003) Recent reports. Madagascar. Bull. Afr. Bird Club 10: 135-136.

Benson, C. W. and Wagstaffe, R. (1972) Porzana olivieri and Limnocorax flavirostris: a likely affinity. Bull. Brit. Orn. Club 92: 160-164.
BirdLife International. (2004) Threatened birds of the world CD-ROM. Cambridge, UK: Birdlife International.

Collar, N. J. and Stuart, S. N. (1985) The threatened birds of Africa and related 
islands. Cambridge, UK: International Council for Bird Preservation.

Foiben Taosarintanin'i Madagasikara (1956) Bekipay. Carte de Madagascar au 1: 100,000, sheet K40. Antananarivo, Madagascar: Service Géographique de Madagascar.

Grandidier, G. and Berlioz, J. (1929) Description d'une espèce nouvelle d'oiseau de Madagascar de la famille des Rallides. Bull. Acad. Malgache 10: 83-85.

Harebottle, D. M. (1999) Wetlands, waterbirds and Madagascar. Bird Numbers 8: 4-7.

Langrand, O. (1990) Guide des oiseaux de Madagascar. Lausanne, Switzerland: Delachaux et Niestlé.

Long, P. R., Zefania, S., ffrench-Constant, R. H. and Szekely, T. (2008) Estimating population size of an endangered shorebird, the Madagascar plover, using a habitat suitability model. Anim. Conserv. 11: 118-127.

Rabenandrasana, M., Virginie, M. C., Sam, T. S., Randrinarisoa, M., Zefania, S., Razafindrajao, F., Razafimahatratra, B., Ravelomanana, T. and Raharivololoniaina, L. (2004) Evaluation écologique et identification des sites potentiels pour la conservation de la biodiversité des zones humides du complexe Mahavavy/Kinkony (Province de Majunga). Unpublished report. Antananarivo: BirdLife International Madagascar Programme.

Rabenandrasana, M., Virginie, M. C., Sam, T. S., Randrianarisoa, M. and Zefania, S. (2007) Les zones importantes pour la conservation des oiseaux (ZICO) Mahavavy - Kinkony, une site pilote dans la mise en place d'un site de conservation dans la région ouest de Madagascar: aperçu sur la faune aviaire et et les activités de conservation. Ostrish 78: 551-552.

Ramanampamonjy, J. R. (1995) Rencontre inattendue avec le Râle d'Olivier Amaurornis olivieri au Lac Bememba. Working Group on Birds in the Madagascar Region Newsletter 5: 5-7.

Rand, A. L. (1936) The distribution and habits of Madagascar birds. Bull. Amer. Mus. Nat. Hist. 27: 134-499.

Robertson, I. (2004) First-ever photographs of Sakalava Rail Amaurornis olivieri and first detailed observations since 1962. Bulletin of African Bird Club. 11: 18-21.

Stattersfield, A., Crosby, M. J., Long, A. J. and Wege, D. C. (1998) Endemic bird areas of the world: priorities for biodiversity conservation. Cambridge, UK: BirdLife International. (Conservation Series 7).

Taylor, B. and van Perlo, B. (1999) Rails: A guide to the rails, gallinules and coots of the world. Mountfield, East Sussex, UK: Pica Press.

Willard, D. E. and Goodman, S. M. (2002) Observation of the Sakalava Rail (Amaurornis olivieri) and other water birds in the region on Andimaka, south of Bekopaka wetland. Working Group on Birds in the Madagascar Region Newsletter 10: 32-33.

MARC RABENANDRASANA*, SAM THE SEING, MARIE CLÉMENTINE VIRGINIE, MIHAJA RANDRIANARISOA

Asity Madagascar (Malagasy League for Bird Conservation), BP 7503. 101 Antananarivo, Madagascar.

SAMA ZEFANIA

Department of Animal Biology, University of Antananarivo, Antananarivo, PO Box 906, Madagascar.

PETER LONG, TAMÁS SZÉKELY

Department of Biology and Biochemistry, University of Bath, Claverton Down, Bath BA2 7AY, U.K.

ROGER SAFFORD

Birdlife International, Wellbrook Court, Girton Road, Cambridge CB3 oNA, U.K.

*Author for correspondence; e-mail: sakalava-rail@mel.moov.mg and marcrabe_iba@yahoo.fr

Received 14 January 2008; revision accepted I April 2008 